\title{
Review of Andrea C. Schalley \& Susana A. Eisenchlas (eds.). 2020. Handbook of Home Language Maintenance and Development: Social and Affective Factors. Berlin/Boston: Walter de Gruyter. ISBN 978-1-5015-1689-4

\author{
Innara A. GUSEYNOVA \\ Moscow State Linguistic University \\ Moscow, Russia
}

For citation:

Guseynova, Innara A. 2021. Review of Andrea C. Schalley \& Susana A. Eisenchlas (eds.). 2020. Handbook of Home Language Maintenance and Development: Social and Affective Factors. Berlin/Boston: Walter de Gruyter. Russian Journal of Linguistics 25 (4). 1126-1135. https://doi.org/10.22363/2687-0088-2021-25-4-1126-1135

Рецензия

\section{Рецензия на книгу}

Andrea C. Schalley \& Susana A. Eisenchlas (eds.). 2020. Handbook of Home Language Maintenance and Development: Social and Affective Factors. Berlin/Boston: Walter de Gruyter. ISBN 978-1-5015-1689-4

\section{И.А. ГУСЕЙНОВА}

Московский государственный лингвистический университет

Москва, Россия

\section{Для цитирования:}

Guseynova I.A. Review of Andrea C. Schalley \& Susana A. Eisenchlas (eds.). 2020. Handbook of Home Language Maintenance and Development: Social and Affective Factors. Berlin/Boston: Walter de Gruyter. Russian Journal of Linguistics. 2021. Vol. 25, № 4. P. 1126-1135. https://doi.org/10.22363/2687-0088-2021-25-4-1126-1135

The book is devoted to current issues of Applied Linguistics, which are discussed across different domains. The main idea of such investigations is the following: now is the time to implement scientific results including language and contemporary communication theories in real life. The same concerns Applied Linguistics, which is aimed at "the solving of real world problems with language 
and communication" (p. V). The analysis, descriptions and solutions delivered by Applied Linguistics can be integrated in everyday life and be effective in social and institutional spheres. The book illuminates strategies, which are efficient for home language maintenance and development. It consists of four parts. Each part addresses sociolinguistic topics and relevant problems of everyday communication and language use.

Part 1 entitled "Terminologies and methodologies" comprises the analysis of the concept "home language" and terms used for describing this phenomenon; the description of different factors which influence language maintenance and development of home language; and the discussion of methodological approaches applied through the investigation of home languages. Part 2 "Bilingual speakers and their families" is devoted to the "FLP" concept - Family Language Policy in bilingual and multilingual families with migrant backgrounds, in families living in communities and in families fully integrated into institutional and social life. Part 3 "Grassroot initiatives" focuses on the local initiatives executed in communities by applying different tools, e.g. social media, Internet resources, language schools capacities, power and authority of communities. Part 4, "The role of society", highlights two institutional aspects: social justice and inclusiveness, on the one hand, and the role of formal education, on the other hand.

The analysis is carried out on macro, meso and micro levels. The macro level allows the authors to describe the language situation on an institutional level with a high extent of abstraction. The micro level analysis is concentrated on the peculiarities of individuals who are members of small social groups (families). "The meso level - sits amidst the macro and micro levels" (p. 3). Language situations are illustrated by the results of surveys and monitorings executed in different countries and communities, as well as in different family types.

In the chapter "Social and affective factors in home language maintenance and development: Setting the scene," Andrea C. Schalley and Susana A. Eisenchlas discuss the differences between the terms minority language - mother tongue heritage language - home language (p. 4) from an interdisciplinary perspective. The social and affective factors define the usage of the above mentioned terms, and their implementation depends on the scientific field and approaches of researchers. In this handbook, the term home language is employed because it represents "relative neutrality on social and affective factors in language maintenance and development" (pp. 4-5). Home language is characterized as a majority language spoken at home and by community members. The handbook also describes heritage language emphasizing that the term is applied in cases when it is necessary to illustrate the intergenerational aspect. According to the handbook, language maintenance can be defined as a couple of measurements taken in families and communities to support the usage of home languages.

The chapter "Making sense of home language and related concepts" by Susana A. Eisenchlas and Andrea C. Schalley is devoted to the examination of the concept of bilingualism from the geographical and ideological perspectives. Whereas the authors employ two notions - 'bilingual' and 'multilingual', the term bilingualism 
is applied as the "umbrella term" (p. 19). It is stressed that languages give access to new knowledge and the lack of linguistic knowledge can "prevent students from achieving their full potential" (p. 18). In the context of the dichotomy between majority and minority languages, it is necessary to note that a lack of language support on an institutional level fails to guarantee sustainability of minority languages and equal access to educational services. The term mother tongue is also taken into account, but it is emphasized that mother tongue includes diverse aspects, and the language used at home can differ from the language of the child's mother. "Heritage language" is normally applied to speakers who originally came from other countries. Heritage languages are used at home for daily communication between representatives of different generations, usually in addition to the mainstream language. In academic use, there are some new abbreviations: "CALD, culturally and linguistically diverse backgrounds/communities (which includes all communities except Anglo-Saxon); LBOTE, language background other than English; and EAL/D, English as an additional language or dialect" (p. 28). As far as home language is concerned, this term is related to bilingual families and denotes the language of communication between all family members. The term home language "has no ideological underpinning, in contrast to many other terms used in the field of educational research" (p. 34).

In the chapter "Researching social and affective factors in home language maintenance and development: A methodology overview," Päivi Juvonen, Susana A. Eisenchlas, Tim Roberts and Andrea C. Schalley discuss methods which are relevant to home language research: a single-method is used for the quantitative or qualitative studies; a mixed-method, which is also called "mixed qualitativequantitative" method (p. 39), is applied for interdisciplinary purposes. The authors argue that the most popular methods are interview and survey. For studies executed on a micro level, the useful methods are observation, interview and focus group method. On a meso level, preference is given to interviews, surveys, observation, testing, etc. The macro level requires text analysis, including ethnographic interviews, fieldnotes, linguistic landscaping, surveys, etc. All data collection methods can be combined according to the main goal of the research.

Another sociolinguistic topic is related to the family phenomenon. It is a complex term, as there are different types of families. The same applies to children. For example, there are biological children, adopted children, etc. In such a context, several sociolinguistic factors must be taken into consideration, for example if those are migrant or non-migrant families, if parents speak the same or different languages, if the speakers are living in communities or in multilingual milieus, etc. But it is to underline that data collection is executed at micro, meso and macro levels. For example, the meso level provides an opportunity to investigate a "larger social unit - the community" (p. 43), and families are traditionally investigated at a micro level. Nowadays it is also crucial to take into account the parameters of community. Not only do we speak about geographical, but also about virtual communities. The macro level allows us to research bodies of authority "such as representatives of schools or municipalities" (p. 46) and also the value systems, 
ideologies, which are relevant to the whole society. Bodies of authority reflect the needs of most representatives of society, including needs of individuals, social groups, children, migrants, etc. All data should be carefully managed, because the figures form the foundation for institutional decisions of language policy makers.

In Part 2, two topics are presented: self-conceptions and affective reactions, and Family Language Policy itself, but the researchers (Annick De Houwer, Yeşim Sevinç, Amelia Tseng, and Judith Purkarthofer) lay emphasis on bilingual situations in different types of families.

In the chapter "Harmonious Bilingualism: Well-being for families in bilingual settings," Annick De Houwer describes "harmonious bilingualism" (p. 63). It is possible to establish it if there is no negative influence of external and internal factors on Family Language Policy (FLP). The author provides examples which illustrate the situation of equal use of two languages at home and in the educational sphere. At the same time, the author underlines that a change of linguistic environment can cause a lack of verbal communication at home and at school. Insufficient social attention to "linguistic diversity" (p. 65) can cause misunderstandings between representatives of different cultures located in the same area. Moreover, in the institutional and educational sphere, children speaking a home language which is not the societal language are confronted with social and ethnic conflicts, so they are to be seen as "victims of peer aggression in classrooms" (p. 68). Such a situation can be avoided by means of teaching children to speak the societal language. That is the reason why it is necessary to establish harmonious bilingualism and to give children a chance to join the "high quality second language instruction program" (p. 69). It is also mentioned that children who speak the societal language at home sometimes suffer as a result of emotional distance, because they cannot bond with other family members: "they would no longer be able to communicate with grandparents and other relatives" (p. 72). Surveys carried out in bilingual families showed that most mothers are satisfied if children are taught both the home and societal language. It is advantageous for children because in this case they do not suffer from misunderstandings in the institutional sphere and can avoid emotional distance in their families.

The chapter "Anxiety as a negative emotion in home language maintenance and development" by Yeşim Sevinç analyzes the factors generating and stimulating negative emotions of family members representing different generations grandparents, parents and children. One of the factors is related to the fact that parents and grandparents speak a home language while children use a societal language at home, or children do not have sufficient knowledge of heritage or home languages. In such circumstances, children feel constant emotional pressure, which can also have a negative impact on their language proficiency. The children feel intimidated, get speech fright, speech anxiety, etc., and "bilingual children may ultimately avoid using the language about which they feel anxious" (p. 98). It is also mentioned that such situations are typical for transnational families.

In the chapter "Identity in home-language maintenance," Amelia Tseng demonstrates the identity problem in transnational families. Identity can be 
constructed on social, emotional, communication and other levels, but in any case "language is an important index of ethnocultural identity" (p. 110). Home and heritage languages play a pivotal role in creating ethnocultural identity and also facilitate communication between all family members. Home-language maintenance creates the social and linguistic framework for children and their further bilingual education.

The chapter "Intergenerational challenges: Of handing down languages, passing on practices, and bringing multilingual speakers into being" by Judith Purkarthofer covers the institutional steps which should be taken to integrate qualified multilingual speakers into community schools, courses and into an education system. Multilingual speakers focused on children's language acquisition contribute to intergenerational interaction and take part in transmitting regional minority languages, languages of migration and diasporic communities.

In the chapter "Family language policy: Foundations, theoretical perspectives and critical approaches," Elizabeth Lanza and Rafael Lomeu Gomes provide examples of Family Language Policy (FLP) existing across different areas and regions. Their methodological approaches are illustrated by the results of different surveys. FLP is considered to be a part of language policy, which helps to preserve home and heritage languages, their norms and rules. The FLP is presented as a system of measurement and includes the following steps: "1. Classic diary studies by linguist parents. 2. Bilingual language acquisition studies focused on central psycholinguistic questions. 3. A turn to a more sociolinguistic approach: the establishment of FLP as a field of inquiry. 4. A turn to include a more diverse range of family types, languages and contexts. 5. A focus on globally dispersed, transnational, multilingual populations, and ever-greater heterogeneity and adaptability in research methods" (p. 155). The authors argue that it is very important to avoid situations when children speak neither home and heritage, nor societal languages. In addition, it is emphasized that home language development and maintenance is an integral part of "family language policies and practices" (p. 168).

The chapter "Factors influencing family language policy" by Xiao Lan CurdtChristiansen and Jing Huang addresses the identity factor, as well as cultural, economic, political and other internal and external factors, which should be taken into consideration because they affect families and their everyday life. It is stressed that internal factors play a substantial role because each of them is connected with family policy and practices. The "emotional factor" (p. 177) is used for heritage language maintenance and for intergenerational communication. The "identity factor" (p. 177) is crucial for keeping "ethnolinguistic origin of the family" (p. 177). "Cultural factor refers to cultural practices and social norms" (p. 177). "Parental impact beliefs" (p. 178) influence the choice of the parents if they educate children in a home language or the children are taught both in home and societal languages. "Child agency" (p. 178) is seen as a power: children play a role of decision makers, they make choices if they learn home and / or societal languages. It is also emphasised that there are many positive examples of bilingual development in the families and in the educational sphere. 
In the chapter "Strategies and practices of home language maintenance," Mila Schwartz highlights the interaction between parents and children in a sociolinguistic context. Parents are considered to be "minority language teachers" (p. 197). It is important to equip the parents with tools which are relevant for home language maintenance on a high level. Strategies and their annotations developed by different researchers are presented in a table (pp. 201-204). Parents, for example, can take the "design of home language environment" strategy (p. 205). It includes joint book reading, joint use of devices intended for language learning, etc. One of the suggested family practices is "goal-directed code-switching" (p. 206). It is based on pragmatic language use in different communicative situations. It helps children to cross language barriers. The language practices are also summarized in a table on pp. 207-210. The author also indicates that many practices and strategies are initiated by family members.

The chapter "Child agency and home language maintenance" by Cassie SmithChristmas demonstrates the role of children in family language policy. Children are considered to be agents using home language as a tool for connecting generations. At the same time, it is argued that children make their contribution by their bilingualism, which is essential for them. Otherwise, if the children do not speak the societal language, they can be excluded from educational, social and professional life in the future.

In the chapter "Future prospects and visions for family language policy research," Åsa Palvianen gives her vision of family language management. The author argues that the language management system should include both family members' experiences and children's perspectives: "focus on child agency" ( $p$. 238), interviews with parents, peculiarities of child-parents interaction, consideration of ethnographic factors, etc. But the most important thing is to use communication technologies which help "to mediate, coordinate and synchronise the daily lives of individually networked family members" (p. 241). Potential research questions are listed in a table on p. 245.

Part 3 describes local experiences of different communities using institutional, educational and cultural tools for home language maintenance.

In the chapter "Social media and the use of technology in home language maintenance," Sabine Little discusses the term "family digital literacy" (p. 257) and focuses on the usage of the "technology and social media in multilingual families" (p. 257). Online games can motivate children to language learning. According to the empirical data, " $82 \%$ of children had generic interest in online or mobile games" (p. 258). For further integration of children into social life, it is important to equip them with information delivered by social media. In such a situation, children get an opportunity to develop their "cultural and social capital" (Bourdieu 1986), e. g. language capital. For educational purposes, all the sources, such as TV, films, DVDs, YouTube and so on, are of great use. Moreover, Sabine Little underlines the potential of "online vocabulary games" (p. 265) which can be integrated into language learning process. The above-mentioned tools help to tune the atmosphere at home, so that all family members could be involved into the language acquisition process on a regular basis. 
In the chapter "Transnational grassroots language planning in the era of mobility and the Internet," Anikó Hatoss attempts to demonstrate the potential of the Internet and its resources which could help all family members to maintain home and societal languages because nowadays people "are local and global at the same time" (Canagarajan 2005). Internet technologies help to create different spaces, for example, mediascapes, technoscapes, financescapes, ideoscapes, etc. All types of spaces are supposed to be multilingual, whereas languages give access to all scapes and provide an opportunity to construct a multilingual cyberspace.

The chapter "Community language schools" by Janica Nordstrom describes the experience and consequent policy of community language schools delivering educational services not only in a societal language, but also in a home language. The author emphasises the role of community members, parent-volunteers, charities and non-government foundations in solving the problems related to language diversity, heritage languages, migration and host communities (p. 295). Joint efforts contribute to the realization of language policy on local and global levels and protect children from social and institutional injustice. Community language schools develop curricula teaching and pedagogy taking into account local and global changes helping to build up a system which correlates with other institutions and, as a result, home languages are neither marginalized nor excluded from the institutional sphere.

Elisabeth Mayer, Liliana Sánchez, José Camacho and Carolina Rodrígues Alzza cover the best practices of local language initiatives based on Indigenous communities in the chapter "The drivers of home language maintenance and development in indigenous communities." It is argued that minority languages "have different degrees of legal recognition" (p. 315). In case the minority language is recognised on an institutional level, it can be seen as "a vehicle for ethnic cultures and economic considerations" (p. 316). Local initiatives are illustrated by measurement taken in different countries to ensure equal human rights, on the one hand, and to maintain minority languages, on the other hand.

In Part 4 the topic "Social justice and inclusiveness" is analyzed by Anthony J. Liddicoat, Nathan Albury, E. Annamalai, Tove Skutnabb-Kangas, Gregory A. Cheatham and Sumin Lim. All the authors pay attention to language policy on macro and meso levels stressing the advantages of linguistic diversity. The maintenance of home languages gives a chance to observe human rights in families, as well as in the institutional sphere, thus ensuring equal access to all education institutions.

In the chapter "Language policy and planning for language maintenance: The macro and meso levels," Anthony J. Liddicoat gives an overview of language maintenance in educational institutions. First of all, the usage of the two terms language planning and language policy - is well-grounded. It is underlined that both terms are applied "to emphasise different aspects of action around language" (p. 337). The author distinguishes two types of language policy and planning (LPP): the first type suggests language status and functions of language varieties, whereas the second type refers to "language-in-education" (p. 339), and its use in teaching 
and learning processes. LPP can be applied on macro and meso levels. On a macrolevel, LPP is realised through language communities which are provided with resources needed for language maintenance. On a meso level, LPP is supported by different organisations, including "individual schools, media and other languageand literacy-related services" (pp. 345-346). Media are also involved in LPP realization making it possible to establish a minority language and cultural groups interested in developing and maintaining it.

The chapter "Language attitudes and ideologies on linguistic diversity" by Nathan Albury discusses the role of ideologies and attitudes in local initiatives because they can be applied as a tool for regulating the "linguistic diversity on macro and micro level" (p. 359). Ideologies and attitudes pave the way for two strategies. The first strategy is geared towards heritage language learning, whereas the other one is oriented towards bilingual education. This is the reason why ideologies and attitudes are considered to be a pivotal regulating mechanism.

In the chapter "Social justice and inclusiveness through linguistic human rights in education," E. Annamalai and Tove Skutnabb-Kangas analyse the role of education. The authors claim that a lack of equal access to an educational system can lead to the "marginalisation of people" (p. 377) and violation of human rights. In this context, minority groups can be seen as vulnerable social groups because they are "minoritised" (p. 378). To avoid such a situation, institutional (laws, conventions, acts etc.) and regional (regional human rights issues) tools should be implemented. Thus, people can choose one or more languages from the institutionally approved "language repertoire" (p. 385) because "every person must have a choice to use his/her language repertoire for the purposes he/she considers beneficial to him/her" (p. 385). To escape "self-exclusion by the minorities," it is necessary to develop a rational language policy. Such a policy is in line with the "multilingual education" concept (p. 388), which substantiates developing two language education programmes.

The chapter "Disabilities and home language maintenance: Myths, models of disability, and equity" by Gregory A. Cheatham and Sumin Lim is devoted to problems related to students who are not capable enough to learn both home and societal languages. In such a situation, some learners "stop speaking their home language in favor of the dominant language" (p. 402). Some parents discourage their children from speaking and learning a home language because, from their point of view, "bilingualism causes or contributes to developmental problems" (p. 403). Some teachers suppose that students have low motivation to second language acquisition. The solution of the problems indicated above is connected with the development of a special social model of disability which can cover sensitive social groups, including minority social identities. Such a social model of disability can be useful for home language maintenance, as well as for educational institutions.

The second topic "Formal education" is presented by Kutlay Yağmur, Latisha Mary and Andrea Young and by BethAnne Paulsrud.

In the chapter "Models of formal education and minority language teaching across countries," Kutlay Yağmur analyses and describes models related to 
experiences existing in different countries. It is posited that policy makers decide which languages will be taught in education institutions. "Formal education models are mostly based on the national priorities of nation-states" (p. 425), and national circumstances impact the policy makers' decisions. At the same time, the concept of multilingual policies is a challenge for education institutions. Institutions have to take into account the current linguistic situation and opt between "rationalized language regime and multilingual regime" (p. 427). Such decisions concerning minority language are arrived at according to nine parameters: target groups, arguments, objectives, evaluation, minimal enrolment, curricular status, funding, teaching materials and teacher qualifications (pp. 433-436).

The chapter "Teachers' beliefs and attitudes towards home languages maintenance and their effects" by Latisha Mary and Andrea Young focuses on the ways children accept values and cultural heritage related to their home language. At the same time, the role of teachers and their beliefs in education and learning process is underlined. It is necessary to take into account children's peculiarities and psychological characteristics. Also very important are parents' beliefs, their attitude to home language, and practices applied in everyday life. The same characteristics apply to teachers, i. e. their education, relation to cultural heritage, language diversity, etc. In conclusion, the authors state that "language ideologies and beliefs about language are extremely powerful forces" (p. 456), as they determine language policy on local and global levels.

In the chapter "The mainstream classroom and home language maintenance," BethAnne Paulsrud studies the co-existence of mainstream and home languages in educational institutions. It is asserted that teachers, due to the increase in migration flows and students' mobility on all education levels, are confronted with linguistic diversity in classrooms. In such circumstances, classroom management is particularly challenging. A majority language can prove to be a solution, because it is officially admitted as the language of education and learning. That said, majority language proficiency can follow no definite pattern, so it is necessary to develop a technology which can help in such a linguistic situation. Paulsrud argues that it is reasonable to implement a pedagogic technology called "translanguaging" (p. 467). This technology provides an opportunity of using home language resources by teaching a majority language. Such a technology requires specific teacher training geared towards handling different languages in the learning process. In conclusion, it is emphasized that "home language maintenance may be managed and supported in the mainstream classroom" (p. 476), yet it calls for teachers training programmes and courses.

(C) Innara Guseynova, 2021
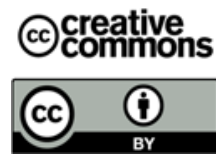

This work is licensed under a Creative Commons Attribution 4.0 International License https://creativecommons.org/licenses/by/4.0/ 


\section{REFERENCES}

Bourdieu, Pierre. 1986. Forms of capital. In John G. Richardson (ed.), Handbook of Theory and Research for the Sociology of Education, 241-258. New York, Greenwood Press.

Canagarajan, A. Suresh. 2005. Reclaiming the Local in Language Policy and Practice. Mahwah NJ: Lawrence Erlbaum.

\section{Book review history:}

Received: 15 May 2021

Accepted: 20 October 2021

\section{Bionote:}

Innara A. GUSEYNOVA (PhD) is Professor \& Vice Rector at Moscow State Linguistic University (MSLU). She is the author of over 150 academic papers, including two monographs and works published in English and German, in the fields of intercultural, professional and marketing communication, institutional communication, applied linguistics, linguistic education, theory of teaching foreign languages and interpretation, and German studies.

\section{Contact information:}

Vice Rector's Office, Moscow State Linguistic University

38, Ostozhenka, Moscow, 119034, Russian Federation

e-mail: guseynova@linguanet.ru

ORCID: 0000-0002-6544-699X

\section{Сведения об авторе:}

Иннара Алиевна ГУСЕЙНОВА - доктор филологических наук, профессор, проректор Московского государственного лингвистического университета (МГЛУ). Автор более 150 публикаций, двух монографий и статей, опубликованных на английском и немецком языках. Область научных интересов - межкультурная коммуникация, профессиональная и маркетинговая коммуникация, институциональная коммуникация, прикладная лингвистика, лингвистическое образование, теория преподавания иностранных языков, межъязыковая коммуникация, германистика.

\section{Контактная информация:}

Московский государственный лингвистический университет

Россия, 119034, Москва, ул. Остоженка, д. 38, стр. 1

e-mail: guseynova@linguanet.ru

ORCID: 0000-0002-6544-699X 